\title{
Italian Attitude Towards the Albanian Issue: Albania's Southern Border at the Conference of Ambassadors in London 1912-1913
}

\author{
Xhilda Shuka \\ Institute of History, University Centre of Albanological Studies, Tirana, Albania \\ Email: xhildashuka@yahoo.com
}

Doi:10.5901/mjss.2015.v6n3p325

\section{Abstract}

This paper aims to analyze the overall attitude of Italy on Albanian issue and in particular the determination of the southern border with Greece in the Conference of Ambassadors in London 1912-1913. The problem of the South Albania and setting of the borders with Greece have implicated as the Balkan states, but also the great powers, like Italy. Italy had politico-strategic interests on Albania, which cross the boundaries of this area. They could not allow the establishment of Greeks on the coast in front of Corfu being a threat to the safety of the Italian state. The issue of Southern Albania connected to solving the Aegean problem or the islands of Dodekanez; unraveling the great Italian interest on Southern Albania. Italian attitude in determining the Greek-Albanian border was in line with the attitude of Austria-Hungary, by creating a common front against the unfair expansionist aims of Greek to Southern Albania (Northern Epirus).

Keywords: Conference of Ambassadors; "Northern Epirus"; southern boundary; Italy.

\section{Introduction}

Albania today represents within its borders a glorious as well as fragmented history. It is the home of Skanderbeg, the national hero of the Albanians, wellknown as Prince of Albania and Epirus. But pride of Skanderbeg, ancient Epirus of Pirro, Epirus of Ali Pasha Tepelena, suffers from painful separation of the London Conference, from the ilyrian agelonging body that has permanently fed. Leaving across the borders of Cameria (South Epirus), 1913, constitutes a major disaster for the Albanian nation but also for Europe with its culture and history. Why did not new Rome (Italy), want new Epirus (Albania) to stand alongside of the golden pantheon of European history and culture, like Athens (Greece) did? With its division Epirus was overshadowed in this pantheon. Namely, starting from this perspective, in this paper we aim to shed light on this historical fact, setting the southern border of Albania, a border that separated Epirus (London Conference of 1913) and the role of Italy in it. Did the Italian state have any opportunity to influence the right solution for this problem?

Italy as one of the countries with geographical but also historical proximity to Balkans had a very important role in setting the southern border of Albania, a role this which in the future would have continuous implications until nowadays. The importance of this border was not merely territorial but also historic, cultural, religious, it assigned the future of ancient Epirus.

This topic is treated in its entirety in the historical literature. While for northern and northeastern border this problem appeared simpler because Serbia-Montenegro claims could not be other than territorial ones; the southern border provinces since the Cameria consisted in a small percentage of the Greek population, and given the old history of Epirus, Greece claims were as historical and territorial, political and religious ones. Given this context, this article aims to shed light specifically on the issue of the southern border in which obviously Italy as a neighbor of Albania and Greece and as one of the participating powers of the London Conference, would play its role.

Domestic and foreign historiography have made valuable contributions on the treatment of this topic, but these publications have not had a particular item to study. The novelty of this paper, stands to the bleaching of Italian politics, Italian residence investigation in relation to the Great Powers, especially with Austria-Hungary against Albania. This new approach represents a challenge that aims to bring to light and to treat with scientific objectivity the truth of Italian politics, especially Italy's diplomatic activity, to explain why Italy pursued a particular policy towards this Albanian issue and which were the reasons for this attitude.

For the realization of this paper it is used the literature selected by major institutions on historical sources as the National Library of Albania, Albanian Central State Archive, the Library of the Academy of Sciences of Albania, the 
Library of the Institute of History of Albania. The literature consists of primary historical sources, such as manuscripts and the dailies of that period, memories of historical persons of the respective period, as well as secondary sources: historical publications and the most significant scientific articles about this issue.

\section{Albanian Issue and the Interests of the Great Powers}

The Albanian issue was placed in the center of the diplomatic war between the Great Powers with the beginning of the First Balkan War, due to their interests in the Balkans.

The victory of the Balkan allies against the Ottoman army forced European countries to abandon the preservation of the status quo on the peninsula. Antanta's countries supported the plans of the allies for the territorial changes at the expense of Albanian lands; actually that was opposed by the powers Tripartite Bond, particularly from Italy and AustriaHungary. They considered Albania as a fence that will prevent the spread of pan-Slavism and Greek influenza and a basis for extending their political and economic influence in Balkans (Albania Academy of Sciences, 2002, pp. 514-515). Italy saw Albania in perspective as "the fifth coast" ("quinta sponda"), as a headbridge for late infiltration of Italian imperialism in the East (Puto, 2009, p.53), as the best means to ensure free sailing across the Adriatic Sea (Zavalani, 1998, p.226).

Disagreements between the Great Powers and the fight of the Albanian people against the foreign yoke dictated the Declaration of Independence of Albania, on 28 November 1912 in Vlora, by the famous patriot and diplomat Ismail Qemali (Academy of Sciences of Albania, 2002, p.515).

On the international plan, independent Albanian state "seen in horror as the illegitimate child of Austrian diplomacy, with Italy that figured as the mom" (Swire, 2005, p.130). Balkan states had no interest and the existence of the Albanian nation didn't suit to them, because they saw it as an obstacle to the realization of their expansionist goals.

One of the contenders of the Albanian land was Greece, which aimed to expand its occupation in Vlora, considering South Albania as the "Northern Epirus", as an integral part of Hellenic heritage (Krisafi, 2007, p.124). Greek media expressed this view in the most brutal way by writing: "It is an impossible thing to let the barbarians Albanians live in the cradle of Greek civilization" (Zavalani, 1998, p.225). But precisely for these "barbarians", the ancient Greek historians themselves had written that they stretched to the bay of Arta, so exactly to the settlements of this period with Albanians.

\section{Italy, Albanian Issue and Southern Border of Albania}

Conference of Ambassadors in London was gathered to mediate the Turkish-Balkan conflict of 1912-1913 and to decide about the political future of the Balkan territories of the Ottoman Empire. It was held (December 1912-August 1913) under the chairmanship of British Foreign Minister Edward Grey. Position and geopolitical and geostrategic importance, the goals of the Balkan countries to the end the conflict with Turkey and intertwining interests of the Great Powers put the Albanian issue at the center of the agenda of the Conference. (Krisafi, 2007, pp.119-120).

During the conference they discussed two aspects of the Albanian issue: the future political status and the setting of boundaries of Albania. Ambassadors decided the creation of autonomous Albania under the "sovereignty or the "suzerenitety" of the sultan, assuming "the guarantee of exclusive control of the six powers" and "proclamation of neutrality". This decision of the international factor marked a step back of the Albanian problem undermining the achievement of the Assembly of Vlora which proclaimed secession from Turkey and the country's full independence. Representatives of Austria-Hungary and Italy were charged with drafting and presentation of a project for organizing the autonomous Albanian state (Academy of Sciences of Albania, 2007, p. 20). Albania, according to this decision, would be still under the framework of the Empire, knowing just the right of internal autonomy. In Conference didn't participate neither the Balkan allies nor Albania, whose voice was not heard because the formula of independence was disregarded.

Italy and Austria-Hungary were for an autonomous or independent Albania with wider borders. Their action in positive complexity, was nevertheless confused with suspicious purposes, each of the two powers, require the new state to enter its sphere of influence (I. Qemali, 2007, pp.367-368). Italy considered Austria-Hungary as a strong competitor, after it became dominant throughout the east coast, owning Vlora, Otranto channel, with an aim to turning the Adriatic sea in an Austrianone. Italy could not be limited to a passive vigilance attitude. Italy had to oppose Austrian influence, at least in the most risked area to it such was southern Albania. At the conference, even if the two countries did not have the same goals, they had a common line of conduct: Albania of Albanians (Giannini, 1940, pp.11-12). At first glance it is a right principle, but it was not clear what each party meant by "Albanian" as a territory.

In its first session, the Conference took overall decisions placing in principle that autonomous Albania bordered in 
the north by Montenegro and south by Greece. Delineation of boundaries was a very sensitive issue that affected many interests as Balkan states but also the powers that were behind them. As at the time of the Berlin Congress, but on a more extensive scale, Albania became the apple of discord between European powers and their satellites in the Balkans. The point was how land of the Ottoman Empire should be divided. (Zavalani, 1998, p.225).

The issue of defining the boundaries fragmented the attitude of the Great Powers, which leded not by the ethnic principle, but by the fulfillment of strategic interests in the region. Austria-Hungary and Italy favored the inclusion of as many territories within the political borders of Albania, necessary for the stability and progress of the country (Swire, 2005, p.133). This is a basically positive attitude but not enough to Albanian concerns that was threatend by numerous enemies, or behind of which stayed significant forces.

In late December and early January 1913 the governments of the allied countries of the Balkans presented in the Conference their views on territorial changes that should be made in the peninsula after the war. However, despite these legitimate demands, based on the principle of nationality, the Balkan allies appeared quite exaggerated claims, driven by chauvinist greeds. These claims touched, firstly, inhabited lands by Albanians. Greece claimed, besides the Greek provinces of Thessaly and parts of southern Albania (which included the Vilayet of Ioannina), inhabited by overwhelmingly Albanian population (Albanian Academy of Sciences, 2007, p.21). While the organization of the new state resulted in serious disagreement, discussion of borders lasted eight months. Italy and Austria would insist in providing boundaries to ensure not only the vitality of Albania (of what would remain), but also contribute to the safety of the Adriatic, preventing Greece from threatening Vlora and strengthen the Corfu Channel (Torre, 1960, pp.421-422).

London Conference began to deal specifically with the setting of the boundaries between Albania and Greece only during the second half of March 1913, after an agreement was reached in general for northern and northeastern borders. By that time the issue was discussed outside the conference especially in bilateral negotiations between Austria-Hungary and Italy, which had previously determined the common position that would keep in the conference. Italy took the leading role in discussing southern border (Academy of Sciences of Albania, 2007, p.25). On 19 March 1913, the Italian ambassador Imperial presented to the Conference of Ambasadors the Austro-Hungarian and Italian joint project for the south borders. According to the project, Janina and a considerable area of southern Albania jointed Greece, while Korca and Gjirokastra remained to Albania (Duka, 2007, p. 34).

This project from one hand, reflected the concern of Vienna not excessively curtailing Albanian territory and especially leaving Korca to Albania. On the other hand, it was Italy's opposition for not leaving the entire coast in front of Corfu to Greece. According to Rome, a Corfu channel all at Greece could constitute a potential danger to the southern coast of Italy (Puto, 2009, p.80). Italy to facilitate reaching an agreement, proposed a boundary on the coast not the discharge of the river Kalamas, but Stillo Cape in front of Corfu (Academy of Sciences of Albania, 2007, pp.25-26). Austro-Hungarian and Italian diplomacy motivated by politics of balance not by the principle of rights for the delineation of the borders of Albania (Bumci, 1920, p.3).

The situation in southern Albania, keeping Greek military forces on the island of Sazan and the threat to blockade from the Greek fleet of the port of Durres, quickly put on alert two powers interested in the Adriatic, which signed on May 8, 1913 in Rome a secret agreement, according to which both powers engaged to conquer and share Albania. Specifically Italy wanted Greece to leave as soon as possible from the occupied territories in the east coast of the Adriatic and especially from Saranda and Gjirokastra. Italian government informed the Greek government that the occupation of both coasts of the Strait of Corfu jeopardized the communication in a channel that was considered vital for Italy. Therefore, this place was even prepared to go to war to prevent such a development. Even Italy began to mobilize the troops to deploy in Vlora (Pearson, 2004, p.42). The agreement provided the possibility of invasion of Albania by their armed forces dividing its territory into two equal parts: Austro-Hungarian would have the provinces over Shkumbin, Italy those south of the river. So Italy in coordination with Austria-Hungary also held positions that highlighted their maximum interest for territorial gains against Albania clearly evidenced in this agreement (Mousset, 2004, p.14). Italian troops began to concentrate in Brindisi. Italian military expedition objectives were Vlora, Saranda and southern Albania up to Shkumbini River. Objectives of Austria-Hungary were Shkodra, Shengjin and North Albania. The official objective of the two powers of the Adriatic, with this project would venture, to impose respect for the decisions of the Great Powers and the establishment of a minimum of public order in the troubled Albania by Turkish militiamen, by interim rival governments, the provincial authorities that were created and arised everywhere in this country, by the Greek troops which threatened Vlora and the Serbian ones who had not yet left the country (Pernice, 191, p.498).

A letter sent from Luigj Gurakuqi to Lef Nosi on May 18, 1913, from Rome, where among other things writes "for the lower boundary of Albania we are trying in London and here, with all the powers: they are ensuring us that Korca and Konica will be ours and by the sea side will not give Greece more than up to the gulf of Ftelias "(the Central State Archive of Albania (AQSH), P. 32, D.55 / 1, p.103). From these words of L. Gurakuqi, we understand that Albanian's hopes to 
preserve their ethnic territories were few. This shows that international opinion had not yet properly assessed Albanian national factor and saw Albania as a territorial expression without significance, except for their interests. While in another state it was justifiable, for Italy, next door to Albanians, Skanderbeg ally, this was unacceptable. Italy as a civilized country, power of the London Conference should have supported the principle of self-determination for the Albanians, the right to live in their lands.

Following the works of the Conference became apparent that the spotlight was the contradiction between Greece and Italy. Italians have been against allowing the Greeks to decide their border in the north of Corfu, having feared that the control of both sides of the canal from a single power would constitute a threat to the security of Italy in the Adriatic (Gurakuqi, 2011, p.43). Albanian southern border issue was complicated with that of Dodecanese. This archipelago was desired by Greece. (Torre, 1960, p. 422).

Why was the issue of South Albania connected with the problem solving of Aegean?

During the Balkan wars the Greek military navy had conquered all previously owned islands of Greece. Italy since the Italian-Turkish war in 1911, carrying the Dodecanese islands occupied. Aegean islands were a tremendous strategic importance after controlling entries and exits from the Dardanelles. Therefore, their future was of vital importance to all the particular powers especially for the powers claiming for dominance in the Mediterranean. Solving the southern border of the Albanian state was linked in this way with the issue of the Aegean islands, because the Italians thought to use the islands held by them as a counterweight to limit the greek claims in the case of and southern borders and in case of issuance of Crete to Greece (Gurakuqi, 2011, p.38). During the Conference of Ambassadors Italy agreed with the proposal made by E. Grey Greece to get Aegean islands occupied by Greek troops, including the Dodecanese held by Italians. Italy agreed with this proposal because it intended to prevent Greek invasion of Epirus. This statement of the Italian government in the last minutes of the London Conference of Ambassadors dated May 30, 1913 and under these circumstances they find out that the Greek government admitted (not saying that was forced to accept) to sign the Treaty of London of May 30,1913, recognizing that the appointment of the border with Albania to be made by Great Powers (Gurakuqi, 2011, p.37). Italy, in agreement with Austria-Hungary, on May 21 presented a second draft containing a concrete description of the borderline. Gjirokastra and Korca remaining within the borders of Albania and the border resulted in Ftelias Bay to Cape of Stillo. In exchange for consent Rome appeared ready to pass Aegean islands to Greece (Puto, 2009, p.80). Italy proposes, contrary to Greece, supported by France, to reach the Albanian border to Cape of Stillo not to relinquish control of the Straits of Corfu, therefore the Strait of Otranto entirely up to Greece, and to include Korca, a major center, a big area inhabited mainly by Albanians, a basic for the future economic prosperity of the new state. (Biagini, 2000, p. 114).

The government of Rome ordered its ambassador in London to insist that the expansion of Greece limited with Kalamas river and city of Preveza in Cameri, taking as his basic requirements that Athens government had submitted to the Congress of Berlin. Fortunately, the British government was convinced that Greece had excessive oppression and Sir Edward Grey, by leaving indifferent position of impartiality, took the side of Albania (Zavalani, 1998, p. 229).

Treaty of 30 May, 1913 was the first international act to express the idea of an Albanian state on its own, but it is not a final act, while the Conference of Ambassadors had still in its agenda the status of Albania (Puto, 2009, pp.61-62). The Greek government is making another attempt to avoid enforcement of the decision of the Great Powers.

In mid-June 1913 Greek Foreign Minister in a meeting with the British ambassador in Athens expressed the greek view. According to him the boundary could begin from the Stillo's bay or Ftelia to continue northwards leaving only a coastal strip to Albania, and Greece would take Gjirokastra and the valley of Drinos, Përmet, Këlcyrë and Korca. It was a sacrifice that Himara and Saranda were left (Kontis, 1976, pp. 107-108). So Greece aspired to take all the province of Epirus (Southern Epirus or Cameria) as well as the North-of the southern Albania to the Seman river. This was a totally unfair request and of chauvinistic character. The government of Vlora and the Albanian patriotic forces were against these claims, seeking diplomatic plan that territory from Korca to Ftelias Bay to remain to Albania.

To support its efforts for a more favorable solution to setting boundaries, by the end of June 1913, the Provisional Government decided to send a special delegation to Rome and Vienna to present requests of Albania to one of the Albanian provinces that threatened more of the greek claims. This was all about Cameria (South Epirus). The delegation presented a memorandum. It was well received in Rome and in Vienna even better. Here it held meetings at various levels, state and private, but heard good words for their predisposition for a fair resolution of the issue of boundaries (Vlora, 2001, pp. 26-27). Now this newly formed state needed secure and internationally recognized borders. The interim government of Vlora, required all territories inhabited by Albanians (Salleo, p. 45).

The agreement about the the coastal border was reached in June according to the proposal of Italy. But it took two months of discussions outside the Conference to resolve the full agreement for all the border between Albania and Greece. Rome and Vienna decided not to make any concessions and announced that they called Korca at east and Cape 
Stillo southwest like "pillars of Hercules" to Albania (Albanian Academy of Sciences, 2007, p. 26).

The final decision of the Conference of Ambassadors is the act of 29 July 1913, the most important in terms of recognizing the independence of Albania. Powers decided the formation of "a sovereign principality hereditary and neutral, under the guarantee of Powers". In this way, after the difficult birth of Vlora on 28 November 1912, it was internationally official recognized baptism of the albanian state (Castellan, 1996, p.397) or act of collective recognition of the independence of Albania by the Great Powers, without which, the act of the Assembly of Vlora would remain simply an expression of aspiration (Puto, 2009, p.63).

Six major powers decided unanimously about the last fate of Dodekanez islands. The proposal made by Grey of 1 August was accepted (Torre, 1960, p. 423).

The draft of the southern border of Albania eventually determined two main points: 1. Boundary line would go from Korca in Cape of Stillos, leaving both of these points and Sazan Island, to Albania; 2. Definitely agreed to a technical committee that would put points on the ground for all domestic provinces, provided that all the islands of the Aegean (which until now Italy had kept as a counterweight to Greece for southern Albanian border), passed to Greece (Puto, 1978, p.251).

If the news of the remnant of Korca and Gjirokastra in Albania enjoyed immensely Albanian patriots across the ethnic regions, the decision to a committee that would set in place the border points "strongly saddened all Albanians who knew intrigues that would Greece use to win our country ". For this reason in Vlora it was organized a meeting which elected a committee, which will be heading to Rome and Vienna to protect "national rights where it was needed." Albanian delegation in Rome failed to meet San Giuliano, but met with his deputy, who promised that Italy would try as it could to protect certain territories of Albania (The Central State Archive of Albania (AQSH), F . 22, D.7 / 1, p.197). Orthodox population of Korca accepted with great joy the news of the remnant of their city in Albania. Alexander Staver Drenova wrote from Bucharest that "these days we received the good news that Korca remained in Albania after the decision of the Ambassadors Conference in London" (The Central State Archive of Albania (AQSH), F 2, D.75, p.76) .

On August 11, 1913, it was determined the southern border of Albania, with the relocation of the southern edge of the river Kalamas at Cape of Styllo; Korca was left to Albania, and Gjirokastra remained with undetermined status. Sazan was left to Albania (Duka, 2007, pp.34-36).

All of these were left to be worked out eventually after the Conference, during the assignment phaze of the borders of Albania. For this reason the Conference of Ambassadors created two International commissions, one for the borders with Montenegro and Serbia, and the other for the border with Greece. The conference set as a criterion to the commission border in the south to comply with the combined ethnogeographic principle. With the establishment of these committees, the Conference of Ambassadors ended on August 12, 1913.

But diplomatic war on the borders of Albania did not end with the closing of the conference, only its center moved from the English capital's palaces in the mountains of Albania (Albanian Academy of Sciences, 2007, p. 26). The new boundaries of the new Albanian state did not make happy none parties, neither the Balkan States which then in turn were disappointed in their ambitions, nor Albania from which were taken the most fertile provinces. Thus the rights of the Albanian nation were sacrificed on the "altar of peace in Europe" (Mousset, 2004, p.13). Delimitation of the boundaries of the new state was in reality a second split, which was more revolting to Albanians. Two-thirds of the Albanian national territory with more than 1.5 million Albanians were separated and distributed to neighboring countries; Greece stretched its boundaries beyond Kallams River, annexing the province of Cameria with its coast from Preveza in the Corfu Channel (The Adriatic Review, 1919, p. 99)

Edward Grey, the British chairman of the London Conference, speaking on August 12, 1913 in the House of Commons concerning the delimitation of the Albanian borders from the London conference, said: "I know very well that when everything will become known, this solution will give rise to major criticism from anyone who knows the place ... the main goal was to preserve the agreement between the Great Powers ... for the good of peace in Europe ". ( Krisafi, 2007, p.136)

\section{Conclusions}

Albanian state dedicates more being but also his not fully being to the Conference of Ambassadors in London in 1913. Shaken protection of the interests of the Albanian issue and Albanian southern border from the Italian state led to the growth of greeds of the Greek state on the southern Albanian lands. If Italy would have kept a principled and steadfast stand about the issue of the Albanian state and its borders then it would be a major obstacle on the Greek aims.

Also dualism of the attitudes of Italy and Austria-Hungary, having as their main point their interests makes a weak link in the chain of problems in the delimitation of the borders of the Albanian state. 
Decisions of the Conference of Ambassadors in London gave a partial, unstable, unfair solution which carried itself more open problems to the Albanians and potential crises and conflicts throughout the Balkans. Decisions of 1913 were a major blow to the cause of Albanians, were a profound reduction of their aspirations, an unfair fragmentation and very painful to the territories and the albanian population. Political boundaries, designed in London were a denial painful operation of territory and the Albanian people, operation that Italy should have eased with its role.

\section{References}

The Academy of Science of Albania (2007). The History of the Albanian People, vol. 3, Tirana: Toena The Academy of Science of Albania (2002). The History of the Albanian People, vol. 2. Tirana: Toena The Adriatic Review (1918). Boston Mass Biagini, A. (2000). Albanian history from Genesis to the present day. Shtëpia e Librit dhe e Komunikimit Bumçi, L. (1920). Albanians and their rights. Shkodër: Shtypshkronja Françeskane

The Central State Archive of Albania (AQSH), F. 32, D.55/1, p.103

The Central State Archive of Albania (AQSH), F. 2, D.75, p.76, letër e Aleks Stavri Drenova nga Bukureshti $26 / 8$ gusht 1913

The Central State Archive of Albania (AQSH), F. 22, D.7/1, p.197, letër e Llambi Pietri (pseudonim i Gjergj Qiriazit), Romë 21 gusht 1913 Duka, V. (2007). History of Albania 1912-2000, Tirana: SHBLU

Georges, C. (1996). History of Balkans (shekulli XIV-XIX). Tiranë: Çabej

Giannini, A. (1940). L'Albania dall'indipendenza all' unione con l'Italia (1913-1939), Milano: Instituto per gli

Studi di Politica Internazionale

Gurakuqi, R. (2011). Principality of Albania and Greece Kingdom, 1913-1914. Tiranë: UET Press

Krisafi, K. (2007). The issue of borders of Albania at the Conference of Ambassadors in London (1912-1913), "Independence of Albania and the challanges of the Albanian state during the XX century. Tirana: Klean Kondis, B. (1976). Greece and Albania 1908-1914, Thessaloniki: Institute of Balkan Studies

Mousset, A. (2004). Albania in front of Europe:1912-1929. Tiranë: Dituria Pearson, O. (2004). Albania and King Zog: Indipendence, Republic and Monarchy 1908- 1939. London; New York :Centre for Albanian Studies

Pernice, A. (1915). Origine ed evolucione strica delle Nazioni balcaniche. Milano: Ulrico Hoepli, Editore Librario della Real Casa

Puto, A. (1978). Albanian independence and the diplomacy of Great Powers Tiranë: 8 Nëntori

Puto, A. (2009). Political Albania 1912-1939. Tiranë: Toena

Qemali, I. (2007). Memories. Tiranë

Salleo, F. Albania six months kingdom. Shtëpia e Librit dhe e Komunikimit

Swire, J. (2005). Albania - the establishment of a monarchy. Tirana: Dituria

Torre, A. (1960). La politica estera dell'Italia dal 1896 al 1914. Bologna: Prof. Riccardo Patron

Vlora, E. (2001). Memories. Tiranë, v.1,2

Zavalani, T. (1998). History of Albania. Tirana: Phoenix 